\title{
GANDHI'S MANAGEMENT OF MASS THROUGH CLOTH-POLITICS
}

\author{
Gyanashree Kotoky \\ Teaching Associate, Department of Political Science, Assam Women's University, \\ Rowriah-785004, Jorhat, Assam, India
}

\begin{abstract}
In the nineteenth century world, certain big powers concentrated in colonializing the resourceful third world countries. England was one such colonial powers with one of its colony as India. It was a leading country in textile industry, thereupon flooded the markets of their colonies with their machine manufactured clothes and the Indian leaders could see the hamper that can be caused upon England if Indians (was a large market for the British) started boycotting foreign clothes. The alternative to foreign cloth was khadi, which was revived back by Gandhi along with the spinning wheel (Charkha), making it a job of every household to spin their own clothes, spin for the nation's interest, that is, to carry the Swadeshi Movement and to earn some money out it. The Khadi Movement was revived with economic motive, and later on, it touched upon spiritual and political aspects on becoming symbol of nationalism. This article analyses Gandhi's managing tactics in the context of huge mass mobilization by trying to inject the same aspiration of freedom during India's Independence Movement.
\end{abstract}

Key words: Gandhi, mass-management, independence movement, mobilization, khadi, spinning-wheel

Cite this Article: Gyanashree Kotoky, Gandhi’s Management of Mass through ClothPolitics, International Journal of Management, 11(12), 2020, pp197-202.

http://iaeme.com/Home/issue/IJM?Volume=11\&Issue $=12$

\section{INTRODUCTION}

In the book Nationalism and Modernism (1998), Anthony D. Smith summed up the elements needed to build up a nation as listed by various theorists. If one relates Smith's words to the condition of India in colonial era, then we can see that no people were equal as the society was divided by the caste, class and sex hierarchy among the Indians and on the other hand inequality existed between the colonials who were the rulers and the Indians upon whom the colonials ruled. Irrespective of the differences among themselves, the indigenous inhabitants of India's only solution was to give priority to the bond of 'citizen and nation-state', hence martyrdom for the freedom of the nation was celebrated. But to develop the 'citizen and nation-state' bond there was the necessity to carve out the territory and hence certain symbols and institutions to develop nationalism were created. The Congress, Khadi, Charkha, the 
national flag, Gandhi cap were such. Accepting those institutions and symbols represented that people residing in those area and their land were a part of the nation-state. Unlike other symbols, the flexibility of the khadi was that all can wear it and cloth is a basic necessity. As a result, khadi became a marker of nationalist spirit. Anthony D. Smith in his book Nationalism and Modernism (1998) calls the territorial states with different ethnic communities wanting to build a nation as 'state-nation' (Smith 1998: 73). Pre-independent India was one such.

The next two sub-sections deal with how economically khadi and the activity of spinning was introduced among the Indians and later on to include more people into the Indian freedom struggle how spirituality was attached to it creating way to make politically active participants of the movement against British administration in India. The two sub-sections are- A Motion for Economy: Traditionalism versus Modernity and Globalisation, which emphasizes on the economic perspective linked with khadi, and Spirituality and Politics, where khadi is analysed on how it was used politically and spiritually.

\section{A MOTION FOR ECONOMY: TRADITIONALISM VERSUS MODERNITY AND GLOBALISATION}

Partha Chatterjee in his book The Nation and Its Fragments (1993) refers to the idea of sovereignty. The Indians were sovereign in the inner domain. The concept of nationalism first developed in this inner domain. As the colonials were not allowed to enter into this sphere, the nationalist leaders used this sphere to create national consciousness among the people (Chatterjee 1993). Gandhi introduced into this sphere the spinning wheel. The basic reason that Gandhi forwarded while asking the Indian mass to spin was that it would make them economically sound. This section will deal with how Gandhi saw economy in khadi and how he approached people to make them adopt spinning.

Self-rule demands sovereignty in economic and spiritual sphere in order to get over the political power. Therefore, swadeshi was only possible through free economy of ones' own, by giving up purchasing of foreign goods. Gandhi readopted khadi as an employment opportunity to the poor. Some writers have associated Gandhi's khadi movement as inclined towards the middle class, but it can be refuted as Gandhi has himself stated in his India of My Dream that- "I think of the poor of India every time I draw a thread on the wheel" (Gandhi 2008: 111). The concern behind this was that Gandhi knew that the largest bulk of Indian mass were poor and to free a country with massive protest the help from this larger section will be needed. Even he knew that this section needs first to fill their stomachs before making them to think for the nation and its freedom. And the experiment started, to search such an occupation. Hence, he writes again,

"For a person suffering from the pangs of hunger, and desiring nothing but to fill his belly, his belly is his God. To him anyone who gives him his bread is his Master. Through him he may even see God. To give alms to such persons, who are sound in all limbs, is to debase oneself and them. What they need is some kind of occupation, and the occupation that will give employment to millions can only be hand-spinning" (Gandhi 2008: 111).

Economy as the ulterior motive and politics as its inner aim, khadi became the solution. Gandhi appealed to use the khadi and the spinning wheel, that is, the cloth industry as an industry next to agriculture and supplementary to the handloom industry. An occupation for the millions and everlasting since cloth is a basic necessity. An alternative work was shown to indulge the poor into work who cannot think of huge investment for start-ups as well as a bridge to bring the mass closer to each other irrespective of the existing differences. The people were shown the benefits of accepting the spinning wheel with the following logic - 
Firstly, spinning was argued as a noble profession having dignity where class, caste does not matter and on the other hand could bring equitability for being a form of labour open to all. In Gandhi's words -

"I can only think of spinning as the fittest and most acceptable sacrificial body labour. I cannot imagine anything nobler or more national than that for, say one hour in the day, we should all do the labour that the poor must do, and thus identify ourselves with them and through them with all mankind. I cannot imagine better worship of God than that in His name. I should labour for the poor even as they do. The spinning wheel spells a more equitable distribution of the riches of the earth" (Gandhi 2008: 111-112).

In the above lines emphasizing on the dignity of manual labour, Gandhi attempted to reach to all the sections to make them use the spinning wheel as a noble profession. Without attributing it with a particular class, he wanted it to be used by all, making it acceptable by to a larger section of people. More people engaged in spinning meant more production of khadi and a stop to the buying of foreign cloths.

Secondly, the spinning wheel is an inexpensive machine, which is more natural than products of craze driven capitalist market. Against the wave of capitalist profit motive driven market, the spinning wheel was revived by Gandhi claiming that the charkha would be 'able to solve the economic distress in a most natural, simple, inexpensive and business, like manner' (Gandhi 1947: 112). Unlike the competition created by the Colonials, Gandhi wanted to provide a shield with the use of traditional ways of working and producing using only that amount of modern machineries necessary, making space for creativity and to help the poor instead of exploiting. Gandhi stated-

"Difficulty is the absence of a ready-market for khaddar. I confess that it cannot for the time being compete with mill cloth. I will not engage in any such killing competition. The capitalist may, for capturing the market, sell his calico for nothing. The manufacturer whose only capital is labour cannot afford to do so" (Gandhi 2008: 113).

He named the new economic movement of recovering the spinning-wheeling and manufacturing khadi as a 'symbol of commercial peace' (Gandhi 2008: 112). A pathway for the poor to 'teach them fishing', making possibility for self-help and an establishment of ecofriendly cottage industry. Along with the revival of the charkha; Gandhi tagged an occupation for the poor, the lazy persons, for farmers and women to use their spare time economically by spinning for the nation. The survival of charkha will help in the survival of 'all the anterior and posterior industries- ginning, carding, warping, sizing, dyeing and weaving' and these again will create scope for the carpenter and the blacksmith. Since Gandhi's aim was to make alive the cottage industry, he used the spinning wheel as a core industry after agriculture, which was to help in creating other jobs for the villagers and hence a village will turn out as self-reliant and economically self-sufficient.

The mill industry though Indian, was exploiting the masses and pushing them more towards poverty. By criticizing the mill-owners as 'not philanthropists to go on providing mill yarn to the handloom weavers', Gandhi asked the weavers to weave their own yarn. Both spinning wheel and handloom are supplementary to each other and hence whatever is related to the spinning wheel had to be swadeshi in nature.

Economy through the reintroduction of spinning wheel and khadi was an approach to reach the millions of people to get their support to start out the political movement. The materialistic symbol of indigenous economy was necessary in creating the base for the movement to catch hold of the ruling power. The colonials got hold of the reign of the Indian political powers only on becoming able to control the economy. They came as traders, destroyed the indigenous economic system and replaced it with the capitalist market system. Hence, to take over the political power, the starting of the movement with the strike on the 
British capitalist economy with swadeshi, emphasizing more on khadi represents that Gandhi used that commodity after knowing it as a basic amenity which can reach to all the mass as well as can affect the trade of British who was leading in the textile industry. When he knew that in the market there is enough khadi to start the khadi movement, only then khadi was used politically. In the use of the khadi as an economic symbol to a political symbol, to get more patronage from the public khadi was attributed with spirituality and morality.

\section{SPIRITUALITY AND POLITICS}

The spinning wheel and the khadi were instruments of non-violence, peace and transquilty. The motion of the wheel as mentioned by Gandhi could bring stability to the ripples in the mind. Running the spinning-wheel was time consuming and patience was required to see the fruit of labour created by the use of this wheel. This built patience in the minds of the spinner and this patience was important to carry a movement for a long period of time. Gandhi could build patience in him and his speeches reflected calmness and peace inhibiting within him. In South Africa he got recognised as a saint. But Mark Shepardin his book Mahatma Gandhi and His Myths stated that Mahatma means 'great soul' but going further Gandhi did not like people calling his saint rather he preferred to refer himself as 'a politician trying to be a saint' (Shepard 2002). His effort to strive for sainthood helped in acquiring spirituality, and this spirituality and attire made him better known among the Indians (Ramagundam 2008). Bhaduri (1973) writes that even in remote tribal areas without ever personally visiting those regions Gandhi became a well-known name with some facts and some misinformation spread around. His celibacy was misinterpreted and got spread as unmarried 'Ganhi baba' who was a vegetarian and moves around naked. The moral power within Gandhi helped him in creating and acquiring consensus of the mass towards him. The simple life he led as advised by Gokhale bore him fruit as it eventually helped him in reaching the poor mass for whom he was 'baba' (saint) (Benarjee-dube 2014).

Gandhi's body politically depicted many unspoken words. His simplicity conveyed through his body covered in khadi attracted the sights of the people. Slowly khadi and the spinning wheel were personified with symbols of morality, spirituality, momentum and religion. Gandhi linked spinning with religion and this in turn assisted in creating space for khadi in the homes of the masses. Spinning was compared to that of cooking one's own food in the home as religious determination required not to eat outside, the same now was applied to wearing home-spun khadi cloth (Gandhi 2008). In India of my Dreams (2008) while Gandhi discussing on the swadeshi doctrine stated of village 'self-supporting' and 'selfcontained' economy where it would be the duty of the villagers to buy the commodity from each other so that each village will be economically sound and shall buy from outside only those commodities which are not produced in that village. He said that it might sound 'nonsensical' in a globalised capitalist economy. But against this nonsensical attribute to the swadeshi supporting Indian Gandhi ironically added the importance of religious influences upon Indians and in turn used religion to make Indians bounded to adopt Khadi. The following quote of Gandhi reflects it-

"Well, India is a country of nonsense. It is nonsensical to parch one's throat with this thirst when a kindly Muhammedan is ready to offer pure water to drink. And yet thousands of Hindus would rather die of thirst than drink water from a Muhammedan household. These nonsensical men can also, once they are convinced that their religion demands that they should wear garments manufactured in India only and eat food only grown in India, decline to wear any other clothing or eat any other food" (Gandhi 2008: 120).

Spinning was also resembled with spirituality when Gandhi appealed the poor to adopt spinning as through it, they could achieve salvation. Even to bring the widows to be part of 
the freedom movement, Gandhi stated about spinning as a 'solace for the widows'. He supported celibacy. If checked history, widows in India were and as still being practiced, are resisted from all kinds of auspicious occasions. Gandhi wanted to get the support of this section of women as the tag against the widows of inauspicious would be reformed as well as this section will not get left out as being left out previously. Moreover, he saw that widows could also be his followers in practicing celibacy. For Gandhi the spiritual aspect of spinning and khadi became more important. The economic purpose with which the charkha was revived was placed now only next to spiritualism. Ramagundam (2008) has summed up Gandhi's spiritual symbolism tagged upon 'spinning' and 'khadi' as - 'sedative for a troubled mind' and 'a great exercise in patience'. Gandhi referred to the patience cultivated by spinning to be useful- while dealing with one's angry wife, for political person who is going through 'incarceration', to deal 'against toxic emotions', and to learn to be simple and industrious. Spinning wheel was in Gandhi's simple words- an emblem with "all the virtues needed to make one's life truthful, pure and peaceful and fill it with the spirit of service" (Gandhi 2008).

With these symbols bestowed upon the spinning wheel, spinning activity and khadi, Gandhi adopted khadi as his identity in the political sphere. The educated Indians, who rowed along the waves of westernaisation, could not develop close connection with the mass that Gandhi could build. Even to the round table conference, Gandhi went in khadi attire, creating and establishing his own identity against the superiorly held western culture. The territorial national community was carved on the basis of the khadi identity one held on the call of Gandhi. Benarjee-Dube (2014) in the book A History of Modern India states of Lisa Trivedi who stated that swadeshists through their figurative displays, khadi tours and exhibitions 'visually reconfigured the map of India'. This helped in building a national community, which further supported 'to lay claim to a national land' (Benarjee-Dube 2014).

The body of the Indians became their identity of belonging to India and symbol of nonviolent resistance and protest against British colonialism. Foucault's idea of body as a site of power was well applied by Gandhi himself and extended to the nation in the form of clothpolitics. The body covered with the khadi piece of cloth manufactured in the homes upon the call of the khadi movement, exhibited to the world the use of cloth for protest and resistance against exploitative colonialism and imperialism at a mass level. The use of body in politics has been discussed by Joselp S. Alter in his book Gandhi's Body: Sex, Diet, and the politics of Nationalism (2000). Here he also stated on how body is used in Asian politics. The body is a presentation of one's identity, which fragments people from one another forming 'we', 'us', 'them', 'they', and 'others'. The body exhibits power, as in the case of India, the body of every khadi wearing India exhibited the urged to be free from the clutch of colonial rule and for that sake, they were ready to face the technologically upgraded colonial force with their khadi and spinning -wheel. The confidence in them reflected in their khadi-attired body. Gandhi in his loincloth travelled across the nation and even sat in the second-round table conference (1931) held in England. It can be resembled with what Dolly Kikon in her article From Loincloth, suits, to Battle Greens: Politics of Clothing the 'Naked' Nagas appeared in the book Beyond Counter-insurgency: Breaking the Impasse in Northeast India stated in case of the Naga community of India. The Nagas were considered primitive, uncivilized and barbaric, and the role to civilise them was undertaken by the colonial rulers. It only led to destruction of the Naga culture, their handloom clothes were replaced by the foreign manufactured clothes brought along by the colonials and their armed forces stationed there. But as youths from the Nagas community made themselves educated they started their resistance against these outer forces by more abruptly holding on their dress while representing themselves outside Nagaland and have re-constructed their past through their 
bodies. They have absorbed influential elements of globalisation but the past culture is never left out, instead the globalization got a glocal character (Kikon 2011).

\section{CONCLUSION}

The bodies adopting khadi were counted as nationalists and spinning which was basically a job of women, was adopted by men too since it was projected as a service to the nation and a remedy to a disturbed mind. To relate spinning with celibacy Gandhi prescribed spinning to young men as a form of therapy to overcome the difficulty in abiding to the norms of brahmacharya (celibacy) (Alter 2000: 19). In another space Alter quoted Gandhi's letter to Harjivan Kotak in 1927 telling him- "Fix your thoughts exclusively on khadi [homespun cotton]; countless men may be wedded to her and yet she always remains a virgin. And a man who takes her alone as a wife will still be an inviolate brahmachari" (Alter 2000: 19). Women who were placed within the four walls of the house, had the responsibility to carry the cultural and spiritual symbols, during the khadi campaign had been provided the scope to spin for the cause of the nation and its freedom, making women come to the public sphere holding along the spiritual elements- khadi and the spinning wheel. Insisting upon spinning to be adopted by everyone irrespective of differences and to spin for atleast half an hour to one hour everyday made communities overcome boundaries set by traditional professions, 'allowing the nationalists to ally with the larger population' (Benarjee-Dube 2014). The nation was built along this line; making people to held khadi in a superior position by preferring to wear it in public. Thus, the nationalists Indians were created by attiring them in khadi and engaging every Indian into spinning.

\section{REFERENCES:}

[1] Alter, Joseph S. (2000), Gandhi's Body: Sex, Diet and the Politics of Nationalism, Philadelphia: University of Pennsylvania Press.

[2] Banerjee-Dube, Ishita (2014), A History of Modern India, Cambridge: Cambridge University Press.

[3] Chatterjee, Partha (2006), "The Nationalist Resolution of the Women's Question", in Kumkum Sangari and Sudesh Vaid (eds.), 2006, Recasting Women: Essays in Colonial History, New Delhi: Zubaan Publications.

[4] Gandhi, M.k. (1938), Hind Swaraj or Indian Home Rule, Ahmedabad: Navajivan Publishing House, originally published in 1909.

[5] Gandhi, M.K. (2016), An Autobiography, New Delhi: Rupa Publications Pvt. Ltd.

[6] Gandhi, Mahatma (2008), India of My Dreams, New Delhi: Rajpal and Sons Publisher, originally published in 1947.

[7] Kikon, Dolly (2009), "From Loincloth, Suits, to Battle Greens: Politics of Clothing the 'Naked' Nagas", in Sanjib Baruah (ed.) Beyond Counter-insurgency: Breaking the Impasse in Northeast India, New Delhi: Oxford (India) University Press, paperback publication 2011.

[8] Ramagundam, Rahul (2008), Gandhi's Khadi: A History of Contention and Conciliation, New Delhi: Orient Longman Private Limited Publications.

[9] Smith, Anthony D and Smith Anthony (1998), Nationalism and Modernism, London: Routledge 